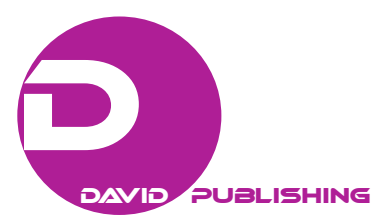

\title{
Applying Gamification for Digital Transformation to a Platform-Based Business
}

\author{
Chun-Yi Lin \\ National Chengchi University, Taiwan
}

\begin{abstract}
The study conducts a single case study and inductive approach to explore how a famous hairdressing chain in Taiwan transforms its business to a platform-centric enterprise in the digital era. In order to deal with its employee resistance to digital transformation resulting from path dependence and increase its employee's engagement in driving digital transformation, gamification is deployed. As a result, the company has reshaped five domains of its business strategy-customer, competition, data, innovation, and value to build a platform. The platform is the key enabler in facilitating interactions among hairdressers and customers. The co-created hairstyle designs will be the resource of this two-sided market formed by hairdressers and customers in this sharing economy.
\end{abstract}

Keywords: digital transformation, gamification, pipleline company, platform company

\section{Research Background}

The advent of digital technologies is reshaping five domains of strategies: customer, competition, data, innovation, and value (Rogers, 2016). New assumptions and rules in these five domains are emerging to transform traditional companies to achieve their next stage of growth in the digital era (Rogers, 2016). First and foremost is to have a customer-centric mindset. Companies strive for creating innovative products and services that deliver values by addressing customers' pain points and gains. Big data technologies are used to capture and analyze interactions among customers, products, and employees to gain insights on new customers' needs and wants. In this way, the competition between companies is changed from traditional value chain strategy into platform business model, which directly connects companies and customers, and creates huge value for both (Rogers, 2016; Alstyne, Parker, \& Choudary, 2016).

Digital technologies enable companies to create a customer-centric strategy. Thus, in the recent years, "platform companies" which facilitate the interactions between consumers and producers have rapidly emerged. The Internet users of such two-sided market will influence each other through common platforms (Eisenmann, Parker, \& Alstyne, 2006). With the more efficient and effective interactions on platforms, users are leaving marketplaces which have no technology platform support (Eisenmann et al., 2006). The companies that own platforms are regarded as platform companies, such as Uber, Airbnb, and Alibaba Group's Alibaba.com, TMall, and Taobao. For traditional non-platform "pipeline companies", such phenomenon is unquestionably a great

Chun-Yi Lin, Ph.D. student, Department of Management Information Systems, National Chengchi University, Taiwan.

Correspondence concerning this article should be addressed to Chun-Yi Lin, Department of Management Information Systems, National Chengchi University, No.64, Sec.2, ZhiNan Rd., Wenshan District, Taipei City 11605, Taiwan. 
pressure of competition. Pipeline companies refer to the companies that focus on one-sided market and adopt traditional value chain strategy based on Porter's five forces model. For pipeline companies and platform companies, their assumptions in the five domains of business strategy are completely different. Thus, in order to face the rise of platform companies, pipeline companies need to figure out how they can reshape these five domains to transform their business strategies from value chain based model to platform-based business model.

However, when companies are facing transformation, path dependence inhibits their transformation due to their successful experience in the past. North likes to explain path dependence for an organization as "inertia" in physics (North, 1990). When people choose a path, no matter good or bad, dependence on this path is formed. In other words, what decisions made by companies in the past will affect possible options they choose presently and in the future. Inertia will constantly strengthen such options. Good path will lead companies to a positive virtuous cycle; bad path will lead to a negative vicious cycle, and companies will be trapped in some condition of inefficiency and stagnate. When they are trapped by such options, transformation will not be realized.

Business gamification has been promoted by academia and practitioners in the recent years to solve the stagnation caused by lack of employee engagement due to path dependence. Since January of 2011, the search for the term "gamification" has rapidly increased on Google search engine (Duggan \& Shoup, 2013). A literature review on the studies of gamification has been increasingly searched from 2010 through 2013 (Hmari, Koivisto, \& Sarsa, 2014). According to Gartner, until 2014, over 70\% of 2,000 companies around the world have at least one gamified application. For example, Nike+ applies gamification on medical care and Marriott applies it on human resources (Dale, 2014).

Thanks to the growth and development of the Internet, gamification is one of the most important trends in this era of experience economy. The term "gamification" was first proposed in the Game Developers Conference 2011. Gamification is defined as the use of game design elements in non-game contexts, and is intended to create gameful and playful user experiences, motivate desired user behaviours, and increase joy of use. This approach has been widely adopted by many industries (Werbach \& Hunter, 2012; Deterding, Dixon, Khaled, \& Nacke, 2011; Thom, Millen, \& DiMicco, 2012). Building a successful gamification program is based on game mechanics combined with the behavioral psychology inherent in social network games. It is able to drive, measure, and award high-value employee behaviors. It increases employee engagement in company's transformation, and is thus an effective way to motivate employees in the digital age (Duggan \& Shoup, 2013).

In sum, this study aims to understand the process of transformation from "pipeline companies" to "platform companies". A gamification program is implemented to solve the problem of path dependence that hinders company transformation, and to develop the five domains of business strategy that lead companies to successful digital transformation.

Company A is the subject of this research. It is one of the top three famous hairdressing chains in Taiwan. It has over 200 branches in Taiwan, and offers services of hair washing, hair cutting, permanent wave, hair coloring, hair treatment, and professional hair product selling, etc. Company A was founded in 1976 and its strategies have been influenced by Porter's five forces model based on traditional value chain mentality. It is a typical pipeline company. However, with the advent of digital technologies, consumer market has been turn from one sided-market to two-sided market. To respond such phenomenon, the core business strategy of the 
Company A has been changed from production orientation to customer orientation. In 2017, Company A developed a mobile application expecting to transform itself into a platform company and reshaped the five domains of its business strategy.

The purpose of the mobile app is to allow hairdressers and customers share resources and hairstyle designs. This platform allows hairdressers receive information of their customers, customer service records, and customer service ratings and feedbacks. They can also search the requests of all customers. For customers, the mobile app allows them to directly receive the profile of hairdressers, their specialty, and successful or failed experience on hair design, etc. Yet, due to the influence of the organizational structure, Company A's found it very difficult to launch its digital transformation. Its employees lacked interest in it, and the digital transformation had resulted in failure. One hairdresser had mentioned:

We clearly know the mobile application platform caters to meeting the market trend. It could help us increasing our sales performance. However, it is a hassle to change what we used to do. Especially we have to serve a lot of customers every day. We really don't have much time left to enter our hairstyle designs and customer experiences in order to comply with the new policy. However, perhaps we would have been more willing to participate in such changes if we could receive instant rewards and feedbacks instead of waiting for several months.

Many digital transformation initiatives have been negatively affected by the employee resistance due to path-dependent behaviors. A gamification program is deployed to increase employee engagement and improve employee satisfaction (Duggan \& Shoup, 2013; Werbach \& Hunter, 2012; Blohm \& Leimeister, 2013). The subject of the study focuses on the employee of Company A's reactions of the gamification program which include a reward system as part of the new policies. Based on the purpose of gamification, this study can be classified as internal gamification or business gamification, which is applied with employees of companies. This enables companies to increase productivity, inspire innovation, motivate employees, and stimulate teamwork (Werbach \& Hunter, 2012).

This study is a typical inductive approach. Firstly, Company A was implemented a gamification program (Duggan \& Shoup, 2013) which enables Company A to increase its employee engagement in the mobile application platform and to successfully transform itself into a platform company. Secondly, the engagement in the mobile application platform was increased through the gamification program; therefore, the study induces the five domains of business strategy to verify the relevance between gamification and digital transformation for companies. Finally, the study discusses challenges and opportunities in digital transformation for a traditional service firm.

\section{Research Method}

Case study methodology is used to carry out this research. A single case study is majorly used to verify the validity of existing theories and analyze the extreme, unique, and rare management context. Generally, the study of a single case is not applicable to systemically establish a new theoretic framework. Scholars who prefer single case study analysis believe that it can thoroughly reveal the contextual background of economic phenomena corresponding to the case, and thus, the reliability of the research can be guaranteed (Dyer, Jr, Wilkins, \& Eisenhardt, 1991; Yin, 1994; Siggelkow, 2007).

The A company, the object of this study, is a hairdressing chain headquartered in Taipei, Taiwan. The company consists of six loosely coupled business entities. It has 217 branches scattered all over Taiwan. Each branch is directly managed by one of the six business entities rather than the headquarters. Each business entity 
has its own principal who determines and implements its own business strategies and is responsible for its own profit and loss.

The study investigated 60 branches and interviewed their store managers over a 12-month period. We selected 60 branches and their store managers for the following reasons: (1) The ratio of the selected branches for each business entity is the same; (2) The locations of the selected branches must cover all cities in Taiwan; and (3) the selected interviewees are all store managers.

The researcher found that the current organizational structure makes integration of sharing of business resources very difficult. The products and services offered by each branches are different. This often resulted in service failures and customer complaints because customers are expecting consistent service offerings and quality from the chain. In addition, hairdressers are not willing to share their designs and customer-serving experiences.

In order to deal with the above issue, the A company developed the mobile application platform. It aims to match hairdressers and customers to the best match through sharing hairdressers and customers. However, the researcher found out that the current organizational structure has led low employee engagement in the mobile application platform. The platform is rolled out in two stages focusing on increasing the engagement via the mobile application. The first stage focused on internal hairdressers' participation. When their engagement has reaches $80 \%$, the second stage will be carried out to engage customers with the platform. This study is limited to the first stage of the implementation plan where Company A deploys a gamification strategy to facilitate the transformation from a traditional firm to a platform company.

Step 1: Identify desirable behaviors of hairdressers that are critical to the success of the platform. Hairdressers' willingness to contribute their hairstyle designs and customer service experiences is the first critical step in making the app work.

Step 2: Define key performance indicators (KPI) to measure the desirable behaviors defined in Step 1. All involved hairdressers on the platform must benefit from shared professional knowledge and skills. Five key performance indicators (KPI) are used to measure the degree of engagement, including sharing personal profile (e.g., names, work experience, and professional skills), personal successful customer service experience (e.g., customer names, branches, and service types), personal customer service failure experience (e.g., customer names, branches, and service types), professional knowledge and skills, and answering questions asked by the headquarter or hairdressers.

Step 3: Design a rewarding system to encourage hairdressers to share and collaborate on the platform. "Recognition" and "monetary" are two types of rewards used to motivate users based on the KPIs defined in Step 2. Recognitions, such as badges, levels, and ranking are intangible rewards. This is designed to confer status in order to motivate users to reach the KPIs. Monetary rewards are one tangible reward, which is designed to redeem a paid leave.

Step 4: Design and implement the gamification mechanism based on the rewarding system developed in Step 3. The specific gamification mechanism is listed in the Table 1 in the following.

Step 5: Choose a gamification framework. Based on the organizational feature of the A company, this study used the gentle guide framework.

Step 6: Conduct data analytic activities. Examine the gamification program's metrics on a monthly basis via digital dashboard including: monthly active users (MAU), daily active users (DAU), retention rate, etc. 
Table 1

The Specific Gamification Mechanism

\begin{tabular}{|c|c|c|}
\hline Types of rewards & Game elements & Desired behaviors and rewards \\
\hline Monetary & Coin & $\begin{array}{l}\text { 1. Complete a personal profile: } 100 \text { points. } \\
\text { 2. Share one successful customer service experience: } 200 \text { points. } \\
\text { 3. Share one customer's service failure experience: } 300 \text { points. } \\
\text { 4. Share professional knowledge or skills: } 400 \text { point. } \\
\text { 5. Answer one question: } 400 \text { points. } \\
\text { Users can gain } 100 \% \text { points if users complete any assigned tasks in time; } \\
\text { otherwise, they only can gain } 80 \% \text { of the deserved points. They can redeem } \\
\text { accumulated } 1000 \text { reward points for one-day paid leave. }\end{array}$ \\
\hline Recognition & Level & $\begin{array}{l}\text { Six levels (1-6 and the highest level is 6): Move up one level for every 1,000 points } \\
\text { accumulated. }\end{array}$ \\
\hline Recognition & Badge & $\begin{array}{l}\text { Six badges: one level up for one badge. The design concept of the badge is derived } \\
\text { from hairstyling tools } \\
\text { 1. Level one (Accumulated 1,000 points): apprentice towel. } \\
\text { 2. Level two (Accumulated 2,000 points): junior assistant mirror. } \\
\text { 3. Level three (Accumulated 3,000 points): senior assistant blower. } \\
\text { 4. Level four (Accumulated 4,000 points): hairdresser scissor. } \\
\text { 5. Level five (Accumulated 5,000 points): lecture hair dye blush. } \\
\text { 6. Level six (Accumulated 6,000 points): expert perm rod. }\end{array}$ \\
\hline Recognition & Ranking & Publish rankings based on accumulated points every week. \\
\hline
\end{tabular}

\section{Findings and Discussion}

Until January of 2018, with the six steps of the gamification program, the engagement rate in the mobile application platform has reached nearly $80 \%$. In order to reach the best rankings and receive rewards, we found that the hairdressers began to share their experience and professional skills, and played the game during fragmentation of working time, e.g., break time.

The five domains of business strategy for Company A's digital transformation are shown in Table 2.

Table 2

The Five Domains of Business Strategy for Company A's Digital Transformation

\begin{tabular}{|c|c|c|}
\hline Domains & Business strategies & Application of the A company \\
\hline Customer & $\begin{array}{l}\text { Create excellent customer experience } \\
\text { through techniques and service experiences } \\
\text { offered by hairdressers on the sharing } \\
\text { platform. }\end{array}$ & $\begin{array}{l}\text { 1. Focus on customer demands for diversified hair design and } \\
\text { personalization, reconsider and define how to match customers with } \\
\text { the best fit hairdresser. } \\
\text { 2. List experiences and techniques offered by hairdressers on the } \\
\text { hairdresser platform to assist customers finding optimized service } \\
\text { resulting in better customer service experiences. } \\
\text { 3. Customers are allowed to show hairstyles done as models for the } \\
\text { hairdressers' designs (to be implemented). }\end{array}$ \\
\hline Competition & $\begin{array}{l}\text { Develop core business competence: } \\
\text { optimize hairdressers' skills, satisfy } \\
\text { customers' personalized hairstyle needs, and } \\
\text { build a sharing platform for business growth. }\end{array}$ & $\begin{array}{l}\text { The optimized matching techniques for customers and hairdressers } \\
\text { on the platform offer precise service to customers. The company } \\
\text { can fulfill customers' personalization services, and cast off the } \\
\text { strategy of low-cost competition of traditional pipeline companies. }\end{array}$ \\
\hline Data & $\begin{array}{l}\text { Transform data into insights and insights } \\
\text { into innovations: data of the best match for } \\
\text { customers and data of techniques and } \\
\text { experiences shared by hairdressers. }\end{array}$ & $\begin{array}{l}\text { Obtain analysis results of the data, increase hairdressers' } \\
\text { experiences, and decrease service failure. Then, with hairdressers' } \\
\text { strengthened skills, enhance the precision of customers matching, } \\
\text { and largely increase their satisfaction in the services. }\end{array}$ \\
\hline Innovation & $\begin{array}{l}\text { Quickly create new hair design through } \\
\text { feedbacks from customers (user-generated } \\
\text { innovation) and innovations are diffused via } \\
\text { techniques and experiences shared by } \\
\text { hairdressers. }\end{array}$ & $\begin{array}{l}\text { Hairdressers analyze customers' preferences and pain points } \\
\text { through feedbacks from customers and hairdressers on the platform. } \\
\text { Innovative products and services can be developed by spotting the } \\
\text { trends provided by data collected via the platform. }\end{array}$ \\
\hline
\end{tabular}


Table 2 to be continued

\begin{tabular}{lll}
\hline Through the sharing platform for designs & $\begin{array}{l}\text { Focus on customer experience and personalized demands, and offer } \\
\text { customers a solution to find optimized hairdressers. The A } \\
\text { and data analytic, companies can offer what } \\
\text { customers value the most. }\end{array}$ & $\begin{array}{l}\text { into the customer-centric platform company. } \\
\text { inted pipeline company }\end{array}$ \\
\hline
\end{tabular}

\section{Conclusions}

In sum, the essence of digital transformation for pipeline companies needs to put more emphasis on strategic change and cultural change than techniques and technologies. In other words, digital transformation is not only about upgrading the IT infrastructure and introducing new technologies. It is an integration of digital technologies, techniques, processes, and most importantly, people, culture, mindset that is truly transforming the way companies do business. In order to deal with the employee resistance to digital transformation because of path dependence, this study firstly focused on increasing employee engagement in the mobile application platform through the internal gamification program. In the next stage, we will study how customer engagement can be increased through gamification as well.

According to the literature reviews and the case study analysis, this study discusses challenges and opportunities for a traditional service firm's transformation to a platform-based business. We found that there are four main issues in leading IT-enabled transformation: leadership with business mindset, IT strategies focusing on creating businesses and customer values, establishment of agile and cross-functional IT organizations, and the development of digital application with user experience as the prime principle. Customers in the service scenario co-create the service outcomes (hairstyle done) and experiences. Helping them to find the right hairdressers is just a critical step towards building the platform that facilitates the interactions among customers and hairdressers by sharing their hairstyle designs and service experiences.

\section{References}

Alstyne, M. W., Parker, G., \& Choudary, S. P. (2016). Pipelines, platforms, and the new rules of strategy. Harvard Business Review, 94(4), 54-60.

Blohm, I., \& Leimeister, J. M. (2013). Gamification: Design of it-based enhancing services for motivational support and behavioral change. Business \& Information Systems Engineering, 5(4), 275-278.

Dale, S. (2014). Gamification: Making work fun, or making fun of work? Business Information Review, 31(2), 82-90.

Deterding, S., Dixon D., Khaled R., \& Nacke, L. (2011). From game design elements to gamefulness: Defining gamification. In Proceedings of the 15th International Academic Mind Trek Conference: Envisioning Future Media Environments (pp. 9-15). ACM.

Duggan, K., \& Shoup, K. (2013). Business gamification for dummies. New York: Wiley.

Dyer, W. G., Jr, Wilkins, A. L., \& Eisenhardt, K. M. (1991). Better stories, not better constructs, to generate better theory: A rejoinder to Eisenhardt; better stories and better constructs: The case for rigor and comparative logic. The Academy of Management Review, 16(3), 613.

Eisenmann, T., Parker, G., \& Alstyne, M. W. (2006). Strategies for two-sided markets. Harvard Business Review, 84(10), 92.

Hamari, J., Koivisto, J., \& Sarsa, H. (2014). Does gamification work? A literature review of empirical studies on gamification. In Proceedings of the 47th Hawaii International Conference on System Sciences (HICSS, pp. 3025-3034). IEEE Computer Society Press.

North, D. (1990). Institutions, institutional change and economic performance. Cambridge: Cambridge University Press.

Rogers, D. L. (2016). The digital transformation playbook: Rethink your business for the digital age. New York: Columbia University Press.

Siggelkow, N. (2007). Persuasion with case studies. The Academy of Management Journal, 50(1), 20-24. 
Thom, J., Millen, D., \& DiMicco, J. (2012). Removing gamification from an enterprise SNS. In Proceedings of the ACM 2012 Conference on Computer Supported Cooperative Work (pp. 1067-1070). ACM.

Werbach, K., \& Hunter, D. (2012). For the win: How game thinking can revolutionize your business. Philadelphia: Wharton Digital Press.

Yin, R. K. (1994). Case study research: Design and methods (2nd ed.). London: Sage Publication. 